\title{
IDENTIFIKASI STRUKTUR BAWAH PERMUKAAN MENGGUNAKAN METODE MAGNETOTELLURIK 2D DI DAERAH CEKUNGAN BINTUNI SEBAGAI POTENSI HIDROKARBON
}

\author{
Ririn Yulianti $^{* 1}$, Syamsurijal Rasimeng ${ }^{1}$, Karyanto $^{1}$, Hidayat ${ }^{2}$, \\ Noor Muhammad Indragiri ${ }^{2}$ \\ 1) Jurusan Teknik Geofisika, Universitas Lampung \\ J1. Prof. Dr. Sumantri Brojonegoro No.1, Bandar Lampung 35145 \\ ${ }^{2)}$ Pusat Survei Geologi (PSG) \\ J1. Diponegoro No. 57, Bandung 40115 \\ ${ }^{3}$ Jurusan Teknik Geofisika, FT UNILA \\ e-mail: $*^{1}$ ririnry12@gmail.com
}

\begin{abstract}
ABSTRAK
Penelitian metode Magnetotellurik (MT) dilakukan pada daerah prospek hirdokarbon di Cekungan Bintuni, Propinsi Papua Barat. Penelitian ini bertujuan mengidentifikasi struktur bawah permukaan berdasarkan penampang resistivitas 2 dimensi. Proses pengolahan data penelitian ini antara lain; (i) proses transformasi data dari domain waktu ke domain frekuensi dengan trasformasi Fourier. (ii) proses filtering dengan robust, dimana robust ini terdiri dari tiga jenis yaitu Robust No Weight, Robust Rho Variance dan Robust Ordinary Coherency. (iii) seleksi XPR dan format data diubah menjadi EDI file. (iv) inversi untuk mendapatkan model penampang resistivitas 2D. Hasil yang didapatkan pada penelitian ini berdasarkan penampang resistivitas 2D yaitu pada formasi Klasafet memiliki nilai resistivitas yaitu $1-20 \Omega \mathrm{m}$ pada kedalaman 0 hingga 1000 meter di bawah permukaan dengan litologi sebagai batu lempung yang diidentifikasikan sebagai caprock, pada formasi Kemblengan nilai resistivitas 20 - $90 \Omega$ m pada kedalaman 3500 meter di bawah permukaan dengan litologi batu pasir gampingan yang diidentifikasikan sebagai reservoir, pada formasi Kemum nilai resistivitas $20-32 \Omega \mathrm{m}$ pada kedalaman 6000 meter di bawah permukaan dengan litologi batu pasir yang diidentifikasikan sebagai basement.
\end{abstract}

\begin{abstract}
Magnetotelluric research was done in hydrocarbon prospect area of Bintuni basin, West Papua province. The purpose of this research is to identificate hydrocarbon prospect in subsurface structure using $2 \mathrm{D}$ resistivity section. Data processing step for the research are; (i) Data transformation from time domain to frequency domain using Fourier transformation. (ii) Filtering process using Robust No Weight, Robust Rho Variance and Robust Ordinary Coherency. (iii) XPR selection and formatting data into EDI file. (iv) 2D resistivity section modeling using inversion. The result of this research based on $2 \mathrm{D}$ resistivity section in Klasafat formation have resistivity value about $1-20 \Omega \mathrm{m}$. From 0 until 1000 meter below the surface the main lithology is claystone that identified as caprock. Kemblengan formation have resistivity value about $20-90 \Omega \mathrm{m}$ in 3500 meter under surface with main lithology lime-sandstone and identified as a reservoir. Tipuma formation have resistivity value about $0.62-2 \Omega \mathrm{m}$ in 8000 meter under surface with main lithology claystone. Kemun formation have resistivity value about $20-32 \Omega \mathrm{m}$ in 6000 meter under surface with main lithology sandstone and identified as a basement.
\end{abstract}

Keywords-2D Magnetotelluric, Hydrocarbon, Reservoir. 


\section{PENDAHULUAN}

Dengan bertambahnya tingkat populasi manusia di suatu negara dan kebutuhan energi sebagai pemenuhan kebutuhan manusia yang semakin bertambah menyebabkan pasokan energi semakin banyak. Salah satu sumber energi yang paling berpengaruh bagia suatu negara yaitu minyak dan gas bumi. Keberadaan dan penyebaran minyak bumi dipengaruhi oleh keadaan geologi setempat dan didapatkan dalam suatu cekungan sedimen.

Salah satu daerah di Indonesia yang memiliki potensi keberadaaan hidrokarbon yaitu Pulau Secara geologi Pulau Papua merupakan hasil tumbukan Lempeng Australia dengan Lempeng Pasifik yang berlangsung dari Miosen Awal hingga sekarang. Akibat adanya tumbukan tersebut sehingga struktur geologi dan bentuk Pulau Papua membentuk cekungancekungan yang diidentifikasi memiliki keberadaan hidrokarbon.

Salah satu cekungan yang dibuktikan dengan kaya akan kandungan fosil-fosil di daerah Papua yaitu Cekungan Bintuni. Maka dari itu pada penelitian ini dilakukan di kawasan cekungan Bintuni untuk mengetahui bagaimana struktur bawah permukaan cekungan yang tersebut dan untuk eksplorasi lanjut.

Untuk mengoptimalkan eksplorasi minyak bumi perlu dilakukan kegiatan studi geofisika dan geologi untuk mengetahui karakteristik struktur bawah permukaan. Salah satu metode geofisika yang dapat digunakan yaitu metode Magnetotellurik (MT). Metode magnetotellurik merupakan metode elektromagnetik pasif yang memanfaatkan sumber magnet $(\mathrm{H})$ dan medan listrik $(\mathrm{E})$ dalam bumi untuk menentukan konduktivitas bawah permukaan bumi.

Dalam penentuan karakteristik struktur bawah permukaan dengan metode magnetotellurik 2D terdapat langkahlangkah yang perlu dilakukan. Pertama- tama melakukan transformasi Fourier untuk mengubah data domain waktu ke domain frekuensi, melakukan filtering noise dengan robust processing, seleksi cross power, melakukan inversi 1D dan inversi 2D.

Penentuan karakteristik bawah permukaan untuk menentukan identifikasi struktur bawah permukaan yang berpotensi hidrokarbon dilakukan dengan mengalisis penampang resistivitas 2D yang telah dihasilkan.

\subsection{Tujuan Penelitian}

Tujuan dari penelitian ini adalah sebagai berikut:

1. Mendapatkan pemodelan penampang resistivitas inversi 2D data magnetotellurik Cekungan Bintuni.

2. Mengetahui nilai resistivitas dan ketebalan lapisan batuan bawah permukaan.

3. Mengidentifikasi struktur geologi batuan potensi hidrokarbon berdasarkan penampang resistivitas 2D data magnetotellurik.

\section{TINJAUAN PUSTKA}

\subsection{Geologi Regional}

Lokasi penelitian ini terletak di area Teluk Bintuni di Kabupaten Papua Barat, Privinsi Papua yang dibatasi oleh luasan Cekungan Bintuni. Lokasi penelitian ditunjukkan pada Gambar 1. Secara geografis lokasi penelitian berada pada $1^{0}$ $42^{\prime} 41.8^{\prime \prime} \mathrm{S}-2^{0} 12^{\prime} 22.6^{\prime}$ ' LS dan $133^{0}$ $23^{\prime} 7.9^{\prime \prime} \mathrm{E}-134^{0} 08^{\prime}$ ' 42.2' ' BT.

Dengan kelompok geologi yang ada di daerah tersebut berupa kelompok tersier berupa formasi Steenkool dengan litologi batu pasir dan lempung, formasi Klasafet dengan litologi batu pasir dan lempung, New Guinea Limestone dengan litologi batu gamping dan lempung. Kelompok 
pretersier berupa formasi Kemblengan dengan litologi batu pasir gampingan dan lempung, formasi Tipuma dengan litologi batu lempung, serta formasi Kemum dengan litologi batu pasir.

Geomorfologi Papua Barat mengalami deformasi pada umur Tersier Akhir, pada masa ini terjadi proses transgresi yang besar yang berarah barat daya dan berakhir pada New Guinea Mobile Belt, sehingga berbentuk kepala dan leher burung. Tatanan geologi daerah KB dibentuk oleh adanya kompresi pada umur Paleogen tepatnya Oligose-Resen (Marten, 2012).

Fisiografi daerah ini dipengaruhi oleh sebaran batuan serta keadaan strukturnya. Setiap satuan fisiografi mencerminkan batuan tertentu. Robinson dkk., (1990) telah mengelompokkan rupa bumi di Teluk Bintuni ke dalam dua empat fisiografi, yaitu : dataran rendah, perbukitan rendah, perbukitan bergelombang dan dataran alluvial.

Cekungan Bintuni terbentuk saat Tersier Akhir yang mengalami perkembangan selama Plio-Pleistosen bersamaan dengan pengangkatan pegunungan lupatan Lengguru (Lengguru Foldbelt) di sebelah timur dan Tinggian Kemum sebelah utara (Pigram dan Sukanta, 1981). Kolom stratigrafi daerah penelitian dapat dilihat pada Gambar 2.

Geologi Papua dipengaruhi dua elemen tektonik besar yang saling bertumbukan dan serentak aktif Gambar 3. Struktur regional Papua terdapat pada Gambar 4 dan elemen tektonik kepala burung Papua terdapat pada Gambar 5.

Tektonik Papua, secara umum dapat dibedakan menjadi dua bagian, yaitu Badan Burung atau Papua bagian timur dan Kepala Burung atau Papua bagian barat. Kedua bagian ini menunjukkan pola kelurusan barat-timur yang ditunjukan oleh Tinggian Kemum di Kepala Burung dan Central Range di Badan Burung, Kedua pola ini dipisahkan oleh Jalur Lipatan Anjakan Lengguru berarah baratdayatenggara di daerah Leher Burung dan juga oleh Teluk Cenderawasih (Dow dan Sukamto, 1984).

\section{TEORI DASAR}

\subsection{Dasar Metode Magnetotellurik}

Metoda magnetotellurik (MT) merupakan salah satu metoda eksplorasi geofisika yang memanfaatkan medan elektromagnetik alam. Medan EM tersebut ditimbulkan oleh berbagai proses fisik yang cukup kompleks sehingga spektrum frekuensinya sangat lebar $\left(10^{-5}\right.$ $\left.\mathrm{Hz}-10^{4} \mathrm{~Hz}\right)$. Pada frekuensi yang cukup rendah (kurang dari $1 \mathrm{~Hz}$ ), solar wind yang mengandung partikel-partikel bermuatan listrik berinteraksi dengan medan magnet permanen bumi sehingga menyebabkan variasi medan EM (Vozoff, 1991).

\subsection{Persamaan Maxwell}

Pada metode MT menggunakan beberapa persamaan, salah satunya yaitu persamaan Maxwell. Persamaan Maxwell merupakan sintesa hasil-hasil eksperimen (empiris) mengenai fenomena listrik magnet yang didapatkan oleh Faraday, Ampere, Gauss, Coulomb disamping yang dilakukan oleh Maxwell sendiri. Dalam bentuk diferensial, persamaan Maxwell dalam domain frekuensi dapat dituliskan sebagai berikut:

$$
\begin{aligned}
& \nabla \times \vec{E}=-\frac{\overrightarrow{\partial B}}{\partial t} \\
& \nabla \times \vec{H}=\vec{I}+\frac{\overrightarrow{\partial D}}{\partial t} \\
& \nabla \cdot \vec{D}=\mathrm{q} \\
& \nabla \cdot \vec{B}=0
\end{aligned}
$$

$$
\text { dimana: }
$$

$\vec{E}$ : vektor medan listrik (volt/m)

$\vec{B}$ : vektor fluks atau induksi magnetik (weber $/ \mathrm{m}^{2}$ atau tesla)

$\vec{H}$ : vektor medan magnet (ampere/m)

$\vec{I}$ : vektor rapat arus (ampere $/ \mathrm{m}^{2}$ ) 
$\vec{D}$ : vektor perpindahan listrik (coulomb $/ \mathrm{m}^{2}$ )

$\mathrm{q}$ : rapat muatan listrik (coulomb $/ \mathrm{m}^{3}$ )

(Telford, dkk., 2004).

\subsection{Skin Depth}

Pada metode MT terdapat skin depth. Besaran skin depth digunakan untuk memperkirakan kedalaman penetrasi atau kedalaman investigasi gelombang elektromagnetik. Adapun skin depth dalam metode Magnetotellurik dapat dituliskan dalam (Persamaan 2) berikut ini:

$\delta=503 \sqrt{\frac{\rho}{f}}$

Dimana $\delta$ adalah kedalaman penetrasi (m), $\rho$ adalah resistivitas medium (ohm. $\mathrm{m})$. Sementara $\mathrm{f}$ adalah nilai frekuensi dari gelombang EM tersebut (Simpson dan Karsten, 2005).

\subsection{Metode Pengukuran MT}

Dalam metode pengukuran MT, terdapat dua metode pengukuran yang dapat membantu dalam proses pemodelan atau interpretasi tahap awal, yaitu antara lain:

1. Transverse Electric Mode

Pada komponen yang menunjukan medan listriknya sejajar dengan arah struktur utama dinamakan Transvers Electric (TE) mode atau juga disebut E-Polarization.

2. Transverse Magnetic Mode

Pada komponen yang menunjukan medan magnet yang sejajar dengan arah struktur utama dinamakan Transverse Magnetic (TM) mode atau disebut juga $B$-Polarization.

(Unsworth, 2006)..

\subsection{Pengolahan Data MT}

Pengolahan data MT dilakukan dari data mentah berupa time series sampai diperoleh nilai resistivitas semu dan fase. Teori yang digunakan pada proses pengolahan data MT diantaranya

1. Fourier Transform untuk mengubah data time series domain menjadi frequency domain menggunakan (Persamaan 3) :

$$
F(\omega)=\int_{-\infty}^{\infty} f(t) e^{-i \omega t} d t
$$

(Rulia, 2012).

2. Robust processing yang berguna sebagai filter noise awal. Robust processing adalah teknik pemprosesan statistical yang menggunakan bobot iterative dari residual untuk mengidentifikasi dan menghapus data yang menyimpang oleh noise (Rulia, 2012).

3. Menghitung nilai dari impedansi. fungsi transfer magnetotellurik untuk memperoleh tensor impedansi adalah sebagai berikut:

$$
\left(\begin{array}{l}
E x \\
E y
\end{array}\right)=\left[\begin{array}{ll}
Z_{x x} & Z_{x y} \\
Z_{y x} & Z_{y y}
\end{array}\right]\left(\begin{array}{l}
H x \\
H y
\end{array}\right)
$$

Resistivitas semu untuk lapisan Bumi diperoleh dari (Persamaan 5):

$\rho_{a}=\frac{1}{\omega \mu}\left|\frac{E_{x}}{H_{y}}\right|^{2}$

Bagian diagonal dari impedansi tensor untuk pendekatan bumi 2-D adalah nol:

dimana

$$
\mathrm{Z}=\left[\begin{array}{cc}
0 & Z_{x y} \\
Z_{y x} & 0
\end{array}\right]
$$

$Z_{x y}=Z_{T E}=\frac{E_{x}}{H_{y}}$
$Z_{y x}=Z_{T M}=\frac{E_{y}}{H_{x}}$

(6b)

Dengan demikian, nilai resistivitas semu dapat didefinisikan sebagai :

$\rho_{x y}=\frac{1}{\omega \mu}\left|\frac{E_{x}}{H_{y}}\right|^{2}$

$\rho_{y x}=\frac{1}{\omega \mu}\left|\frac{E_{y}}{H_{x}}\right|^{2}$

sedangkan fase, dapat didefinisikan sebagai : 


$$
\begin{aligned}
& \Phi_{x y}=\tan ^{-1}\left(\frac{\operatorname{im}\left(\frac{E_{x}}{H_{y}}\right)}{\operatorname{re}\left(\frac{E_{x}}{H_{y}}\right)}\right) \\
& \Phi_{y x}=\tan ^{-1}\left(\frac{\operatorname{im}\left(\frac{E_{y}}{H_{x}}\right)}{\operatorname{re}\left(\frac{E_{y}}{H_{y}}\right)}\right)
\end{aligned}
$$

(Dewi, 2012).

4. Melakukan inversi 1 dimensi dengan menggunakan metode inversi Bostick dan inversi Occam sedangkan inversi 2 dimensi menggunakan metode inversi Nonlinear Conjugate Gradient (NLCG) (Amriyah, 2012).

\subsection{Petroleum System}

Petroleum system merupakan sebuah sistem yang menjadi panduan utama dalam eksplorasi hidrokarbon. Sistem ini digunakan untuk mengetahui keadaan geologi dimana minyak dan gas bumi terakumulasi (Koesoemadinata, 1980).

1. Batuan Sumber

Batuan sumber adalah batuan yang merupakan tempat minyak dan gas bumi terbentuk. Pada umumnya batuan sumber ini berupa lapisan serpih (shale) yang tebal dan mengandung material organik.

2. Migrasi

Migrasi adalah perpindahan hidrokarbon dari batuan sumber melewati rekahan dan pori-pori batuan waduk menuju tempat yang lebih tinggi.

3. Batuan Reservoar

Batuan reservoar merupakan batuan berpori atau retak-retak, yang dapat menyimpan dan melewatkan fluida.

4. Lapisan penutup

Lapisan penutup merupakan lapisan pelindung yang bersifat tak permeabel yang dapat berupa lapisan lempung, shale yang tak retak, batugamping pejal atau lapisan tebal dari batuan garam.

5. Perangkap (trap)

Secara geologi perangkap yang merupakan tempat terjebaknya minyak dan gasbumi dapat dikelompokan dalam tiga jenis perangkap, yaitu perangkap struktur, perangkap stratigrafi dan perangkap kombinasi dari keduanya.

\section{METODE PENELITIAN}

\subsection{Alat dan Bahan}

Adapun alat dan bahan yang digunakan dalam kerja praktek ini adalah sebagai berikut:

- Laptop Acer Aspire 4732

- Software Synchro Time Series View

- Software SSMT2000

- Software MTEditor

- Software WinGlink

- Software Microsoft Word dan Microsoft Excel 2007

\subsection{Pengolahan Data}

\subsubsection{Proses Transformasi Fourier (FFT)}

Data yang dihasilkan dari perekaman alat MT berupa time series, untuk melakukan pengolahan selanjutnya dilakukan pengubahan data dari domain time series ke domain frekuensi untuk mendapatkan nilai resistivitas dan phase. Pengubahan data time series ke frekuensi dapat dilakukan dengan transformasi Fourier pada software SSMT2000 ditunjukkan pada Gambar 6.

\subsubsection{Robust Processing}

Data yang telah menjadi domain frekuensi masih terdapat noise, untuk mereduksi noise atau filtering noise perlu dilakukan robust processing. Robust processing memiliki tiga tipe, yaitu robust no weight, rho variance dan ordinary coherency. Proses robust ditunjukkan pada Gambar 7.

Setelah melakukan ketiga robust tersebut, selanjutnya menghitung nilai 
koherensi masing-masing robust. Untuk nilai koherensi yang tertinggi dilakukan robust processing upgrade. Kemudian hitung kembali nilai koherensi robust processing upgrade, apabila nilai koherensi $\geq 75 \%$ maka dapat dilanjutkan ke tahapan proses selanjutnya. Tetapi apabila nilai koherensi $\leq 75 \%$ maka dilakukan combine. Settingan robust processing upgrade ditunjukkan pada Gambar 8.

\subsubsection{Seleksi Time Series}

Data mentah hasil pengukuran di lapangan merupakan data medan elektromagnetik yang terekam terhadap waktu. Pengukuran MT yang dilakukan selama 1 hari penuh menyebabkan data yang diperoleh untuk satu stasiun cukup panjang. Dari panjangnya data yang diperoleh tersebut, tidak semua data merupakan data yang baik. Kemungkinan adanya noise dalam data masih sangat besar terjadi. Noise tersebut dapat mempengaruhi nilai koherensi yang diperoleh, untuk mendapatkan nilai koherensi yang besar dapat dilakukan dengan beberapa cara, salah satunya dengan seleksi time series ditunjukkan pada Gambar 9.

\subsubsection{Seleksi Cross Power}

Setelah memperoleh data dalam domain frekuensi maka data tersebut dapat dibuka dalam program MTEditor. Data tersebut ditampilkan dalam bentuk 2 kurva MT yaitu kurva frekuensi vs apparent resistivity dan kurva frekuensi vs phase. Kurva yang ditampilkan masih acak atau belum teratur. Oleh karena itu, perlu dilakukan proses seleksi cross power untuk memperoleh kurva MT yang lebih baik lagi. Kurva sebelum dilakukan seleksi ditunjukkan pada Gambar 10a Kurva setelah dilakukan seleksi ditunjukkan pada Gambar 10b.

\subsubsection{Inversi}

Inversi merupakan kegiatan untuk mendapatkan model kondisi bawah permukaan, proses inversi dilakukan dengan menggunakan software WinGlink. Inversi dilakukan dengan 2 tahapan, yaitu inversi 1 dimensi yang ditunjukkan pada Gambar 11 untuk mengetahui nilai resistivitas serta ketebalan masing-masing lapisan. Yang kedua yaitu inversi 2 dimensi untuk mendapatkan penampang resistivitas 2 dimensi untuk dilakukan interpretasi.

\section{HASIL DAN PEMBAHASAN}

\subsection{Hasil Pengamatan}

Data yang digunakan dalam penelitian ini merupakan data sekunder Magnetotellurik di kawasan Cekungan Bintuni yang terletak di Pulau Papua bagian barat. Pada penelitian ini menggunakan data pengukuran sebanyak 1 lintasan dengan jumlah titik pengukuran MT sebanyak 5 titik. Waktu pengukuran MT dilakukan selama \pm 12 jam. Arah lintasan pengukuran yaitu timurlaut baratdaya.

Pengolahan data yang dilakukan bertujuan untuk mengurangi atau mereduksi noise pada data telah dilakukan dengan hasil yang baik. Dari 5 titik memiliki nilai koherensi berbeda - beda ditunjukkan pada Tabel 1. dan telah ditingkatkan menggunakan tiga pengolahan robust processing ditunjukkan pada Tabel 2, kemudian dilakukan upgrade robust ditunjukkan pada Tabel 3. Untuk koherensi di bawah $75 \%$ dilakukan seleksi time series pada Tabel 4.

Pada Tabel 4. terlihat nilai koherensi setelah dilakukan seleksi time series bertambah atau naik. Tetapi terdapat tiga titik dengan nilai koherensi masih dibawah $75 \%$. Setelah melakukan seleksi time series, semua titik pengukuran baik dengan nilai koherensi di atas $75 \%$ maupun di 
bawah $75 \%$ dilanjutkan melakukan proses seleksi cross power. Tahap seleksi cross power dilakukan dengan mengedit atau smoothing kurva apparent resistivity dan phase.

Dari ke-5 data tersebut, masingmasing kurva memiliki kualitas data yang berbeda-beda. kreteria dari kualitas kurva MT dilihat berdasarkan trend dan error bars. Terdapat 4 kriteria dari kualitas kurva MT yaitu, Excelent, Very Good, Good dan Fair. Pembagian kelompok dari masing-masing kurva terdapat pada Tabel 5.

Setelah medapatkan kurva yang lebih smooth hasil dari seleksi cross power, maka dilakukan perhitungan kembali nilai koherensi dari masing-masing data. Hasil yang didapatkan yaitu terdapat pada Tabel 6.

\subsection{Pembahasan}

\subsubsection{Hasil Inversi 1D}

Pada inversi 1D akan menghasilkan kurva ketebalan lapisan beserta nilai resistivitas sebenarnya masing-masing lapisan. Kurva inversi 1D ini ditunjukkan pada Tabel 7 hingga Tabel 11.

\subsubsection{Hasil Inversi 2D}

Inversi 2D terdiri dari satu lintasan dengan jumlah titik pengukuran sebanyak 5 titik dengan kedalaman sampai dengan 10000 meter di bawah permukaan.

Pemodelan 2D dimaksudkan untuk mengekstrasi informasi yang terkandung dalam data untuk memperkirakan distribusi tahanan jenis di bawah permukaan melalui model-model. Model hasil penampang inversi 2D terdapat pada Gambar 12.

Untuk mengetahui informasi distribusi tahanan jenis di bawah permukaan melalui model-model penampang 2D, perlu dilakukan korelasi antara informasi geologi daerah penelitian dari peta geologi lembar Ransiki dengan hasil penampang inversi
2D MT seperti pada Gambar 13. dan nilai tahanan jenis dari suatu batuan seperti pada Tabel 12.

Bersadarkan hasil interpretasi pada Gambar 13, pada daerah penelitian ini dari arah Baratdaya-Timurlaut yaitu pada bagian permukaan terdapat endapan tersier, dimana pada endapan tersier ini terdapat formasi Steenkool didominasi batu pasir dan batu lempung, formasi Klasafet di dominasi dengan batu pasir atau di dominasi batu lempung yang dibedakan dengan besar nilai resistivitas.

Di bawah endapan tersier terdapat endapan New Guinea Limestone, berdasarkan penelitian terdahulu endapan limestone pada petroleum system di Cekungan Bintuni dengan range nilai resistivitas tinggi merupakan endapan yang memiliki potensi sebagai reservoir. Berdasarkan petroleum system cekungan Bintuni untuk batuan reservoir pada cekungan ini terbagi menjadi dua jenis yaitu berupa batu pasir pada formasi Kemblengan dan batu gamping pada endapan New Guinea Limestone.

Di bawah endapan New Guinea Limestone terdapan endapan pretersier. Endapan pretersier terdiri dari formasi Kemblengan di dominasi batu pasir gampingan dengan nilai resistivitas tinggi dan formasi Tipuma di dominasi batu lempung dengan nilai resistivitas rendah. Endapan pretersier dengan nilai tahanan jenis yang rendah merupakan endapan yang memiliki potensi sebagai sourcerock pretersier di Cekungan Bintuni. Kemudian di bawah endapan pretersier formasi Kemum merupakan basement.

Penampang resistivitas 2D yang dihasilkan dapat disesuaikan dengan informasi geologi berdasarkan interpretasi geologi daerah penelitian dan nilai resistivitas batuan. Penampang resistivitas 2D terdapat pada Gambar 14.

Lintasan titik pengukuran MT ini memotong 2 lokasi rembesan minyak, yaitu titik BN05 dan BN06 yang dapat dilihat pada Gambar 14. Pada titik BN06 terdapat singkapan batuan yang diduga 
pernah menjadi menjadi tempat keluarnya minyak (migration) ditandai dengan adanya singkapan yang rekah dan terisi oleh jejak hidrokarbon yang terlihat pada Gambar 15. Singkapan yang terbentuk dengan litologi batu pasir dengan nilai resistivitas $50-100 \Omega \mathrm{m}$.

Pada Gambar 14. Terlihat minyak tidak terperangkap di dalam reservoir dikarenakan adanya struktur yang mengontrol keluarnya minyak di permukaan. Tempat potensi migas terperangkap ditunjukkan dengan adanya klosur yang terbentuk, yaitu pada klosur berbentuk horst.

Berdasarkan penampang reistivitas 2D terdapat endapan tersier dengan beberapa formasi yang terendapkan, yaitu formasi Klasafet dengan nilai resistivitas rendah yaitu $1-20 \Omega \mathrm{m}$ dari kedalaman 0 hingga 1000 meter di bawah permukaan dengan litologi batu lempung diidentifikasikan sebagai caprock. Pada endapan New Guinea Limestone terdapat formasi Imskin dengan nilai resistivitas yang cukup rendah yaitu $0.62-6 \Omega \mathrm{m}$ dari kedalaman sekitar 1000 hingga 3500 meter di bawah permukaan dengan litologi batu lempung. Pada endapan pretersier ini terdapat dua formasi yang terbentuk yaitu formasi Kemblengan memiliki nilai resistivitas batuan yang besar yaitu $20-90 \Omega m$ dengan litologi batu pasir gampingan diduga sebagai reservoir yang terdapat pada kedalaman sekitar 3500 meter di bawah permukaan. Formasi kedua yaitu formasi Tipuma memiliki nilai resistivitas batuan yang rendah antara $0.62-2 \Omega m$ dengan litologi batu lempung yang terdapat pada kedalaman sekitar 8000 meter di bawah permukaan.

Dibawah formasi Tipuma terdapat formasi Kemum dengan nilai resistivitas batuan yang rendah yaitu antara $4-20 \Omega \mathrm{m}$ dengan litologi batu lempung dan nilai resistivitas batuan yang tinggi yaitu antara $20-32 \Omega m$ yang dengan litologi batu pasir merupakan basement dari Cekungan
Bintuni terdapat pada kedalaman sekitar 6000 meter di bawah permukaan.

\section{KESIMPULAN DAN SARAN}

\subsection{Kesimpulan}

Berdasarkan hasil penelitian tersebut dapat disimpulkan sebagai berikut:

1. Pemodelan penampang resistivitas inversi 2D sebanyak 1 lintasan memiliki nilai RMS error sebesar $1.8574 \%$ terdiri dari 5 titik data dengan kualitas data yang berbeda beda, antara lain untuk data yang excelent terdiri dari titik BN01 dan $\mathrm{BN} 03$, very good terdiri dari titik BN05, good terdiri dari titik BN04 dan fair terdiri dari titik BN06.

2. Formasi Klasafet memiliki nilai resistivitas 1 - $20 \Omega \mathrm{m}$ pada kedalaman 0 hingga 1000 meter di bawah permukaan dengan litologi batu lempung, formasi Imskin nilai resistivitas $0.62-6 \Omega \mathrm{m}$ pada kedalaman 1000 hingga 3500 meter di bawah permukaan dengan litologi batu lempung, formasi Kemblengan nilai resistivitas $20-90 \Omega \mathrm{m}$ pada kedalaman 3500 meter di bawah permukaan dengan litologi batu pasir gampingan, pada formasi Tipuma nilai resistivitas $0.62-2 \Omega \mathrm{m}$ pada kedalaman 8000 meter di bawah permukaan dengan litologi batu lempung, pada formasi Kemum nilai resistivitas $20-32 \Omega \mathrm{m}$ pada kedalaman 6000 meter di bawah permukaan dengan litologi batu pasir.

3. Struktur bawah permukaan yang diidentifikasi yaitu didapatkan adanya formasi hidrokarbon yang di Cekungan Bintuni berdasarkan penampang resistivitas $2 \mathrm{D}$ adalah batu lempung pada formasi Klasafet diduga sebagai caprock, batu pasir gampingan pada formasi Kemblengan diduga sebagai reservoir, batu pasir pada 
formasi Kemum diduga sebagai basement.

\subsection{Saran}

Saran yang dapat diberikan yaitu dalam pengukuran data Magnetotellurik perlu dilakukan pengulangan pengukuran pada data yang tergolong buruk agar pada saat pemrosesan data mendapatkan hasil maksimal. Dikarenakan apabila pengukuran dilakukan kurang maksimal maka data yang akan dihasilkan pun tidak begitu baik.

\section{DAFTAR PUSTAKA}

Amriyah, Q., 2012, Pemodelan Data Magnetotellurik Multidimensi Untuk Mendelineasi Sistem Geotermal Daerah Tawau, Malaysia, Skripsi Studi Fisika-FMIPA, Depok : Universitas Indonesia.

Dewi, R., 2012, Pemrosesan Data Magnetotellurik Dengan Memperhitungkan Faktor Kalibrasi Menggunakan Matlab, Skripsi Studi Fisika-FMIPA, Depok : Universitas Indonesia.

Dow, D. B., \& Sukamto, R., 1984, Western Irian Jaya: the end-product ofoblique plateconvergence in the LateTertiary, American Association of Petroleum Geologists, Also published in Bulletin of the Geological Research and Development, Centre, Indonesia.

Hamilton, W. R., 1979, Tectonics of the Indonesian Region, Geological Survey Professional Paper, US.

Koesoemadinata, R. P., 1980, Geologi Minyak dan Gas Bumi, Jilid 1, ITB.

LEMIGAS, 2005, Kuantifikasi Sumberdaya Hidrokarbon Cekungan Bintuni, LEMIGAS, Jakarta,
Marten, R, 2012, Lithology and Fluid Prediction refresher, The Use (and Abuse) of Geophysics in Hydrocarbon Exploration and Development, BP Indonesia, Unpublished.

Pigram, C. J., \& Sukanta, U., 1981, Report on the geology of the Taminabuansheet area. Indonesian Geological Research and Development Centre, Open File Report.

Robinson, G. P., Ryburn, R. J., Harahap, B.H., Tobing, S.I., Achdan, A., Bladon, G.M. \& Pieters, P.E., 1990, Geologi Lembar Steenkool, Irian Jaya (Geologi of the Steenkool Sheet area, Irian Jaya), Geological Research and Development Centre, Indonesia.

Rulia, C., 2012, Pengolahan Data Magnetotellurik 2-Dimensi Pada Lapangan Panasbumi Marana, Sulawesi Tengah, Skripsi Studi Fisika-FMIPA, Depok : Universitas Indonesia.

Simpson, F. \& Karsten, B., 2005, Pratical Magnetotellurics, Cambridge : Cambride University Press.

Telford, W. M., Geldart, L. P., \& Sheriff, R. E., 2004, Applied Geophysics Second Edition, Cambridge : Cambridge University Press.

Unsworth, 2006, Overview of Electromagnetic Exploration Methods, University of Alberta.

Vozoff, K, 1991, The Magnetotelluric method, Electromagnetic Methods in Applied Geophysics-Application, Geophysics, Vol. 2, SEG Publishing. 
LAMPIRAN

Tabel 1. Nilai koherensi raw data

\begin{tabular}{|c|c|c|c|}
\hline \multirow{2}{*}{ STATION } & \multicolumn{3}{|c|}{ KOHERENSI RAW DATA } \\
\cline { 2 - 4 } & $R V$ & OC & $N W$ \\
\hline BN01 & 90.1592 & 90.4375 & 88.3544 \\
\hline BN03 & 88.9836 & 88.8361 & 87.9948 \\
\hline BN04 & 58.117 & 59.966 & 43.9974 \\
\hline BN05 & 78.8826 & 80.5187 & 78.6339 \\
\hline BN06 & 63.9559 & 65.4299 & 62.916 \\
\hline
\end{tabular}

Tabel 2. Nilai koherensi hasil robust terbaik

\begin{tabular}{|l|l|l|l|}
\hline \multirow{2}{*}{ STATION } & \multicolumn{3}{|c|}{ ROBUST TERBAIK } \\
\cline { 2 - 4 } & Rho $X Y$ & Rho $Y X$ & AVERAGE \\
\hline BN01 & 91.04689 & 89.82814 & 90.4375155 \\
\hline BN03 & 92.92065 & 85.04649 & 88.9835721 \\
\hline BN04 & 64.75795 & 55.17402 & 59.9659861 \\
\hline BN05 & 85.80477 & 75.23273 & 80.5187495 \\
\hline BN06 & 65.38363 & 65.47614 & 65.4298826 \\
\hline
\end{tabular}

Tabel 3. Nilai koherensi hasil upgrading robust

\begin{tabular}{|c|c|c|c|}
\hline \multicolumn{4}{|c|}{ UPGRADING ROBUST } \\
\hline ROBUST & Rho XY & Rho YX & AVERAGE \\
\hline OC UP & 91.0996 & 91.8170 & 91.4583 \\
\hline RV UP & 93.8782 & 85.8454 & 89.8618 \\
\hline OC UP & 70.2400 & 58.3380 & 64.2890 \\
\hline OC UP & 85.7408 & 76.2312 & 80.9860 \\
\hline OC UP & 67.4260 & 72.8206 & 70.1233 \\
\hline
\end{tabular}

Tabel 4. Hasil koherensi seleksi time series

\begin{tabular}{|c|c|c|}
\hline \multicolumn{3}{|c|}{$T S$} \\
\hline Rho XY & Rho YX & AVERAGE \\
\hline- & - & - \\
\hline- & - & - \\
\hline 83.77402 & 61.30295 & 72.53848536 \\
\hline- & - & - \\
\hline 73.31285 & 69.2556 & 71.28422606 \\
\hline
\end{tabular}

Tabel 5. Pengelompokkan Kurva

\begin{tabular}{|c|c|c|c|}
\hline \multicolumn{4}{|c|}{ PENGELOMPOKKAN KURVA } \\
\hline EXCELENT & VERY GOOD & GOOD & FAIR \\
\hline BN01 & BN05 & BN04 & BN06 \\
\hline BN03 & & & \\
\hline
\end{tabular}

Tabel 6. Hasil koherensi seleksi cross

power
\begin{tabular}{|c|c|c|c|c|}
\hline \multirow{2}{*}{ STATION } & \multicolumn{4}{|c|}{ XPR } \\
\cline { 2 - 5 } & ROBUST & Rho XY & Rho YX & AVERAGE \\
\hline BN01 & OC UP & 91.51804 & 92.79604 & 92.157039 \\
\hline BN03 & RV UP & 94.04963 & 85.85107 & 89.950348 \\
\hline BN04 & OC UP & 83.0623 & 59.62062 & 71.341459 \\
\hline BN05 & OC UP & 85.84945 & 76.29041 & 81.06993 \\
\hline BN06 & OC UP & 69.71217 & 66.19208 & 67.952125 \\
\hline
\end{tabular}

Tabel 7. Resistivitas sebenarnya dan ketebalan lapisan pada titik BN01

\begin{tabular}{|r|r|r|l|}
\hline $\begin{array}{c}\text { Depth } \\
\text { to Top } \\
(m)\end{array}$ & $\begin{array}{c}\text { Depth } \\
\text { to } \\
\text { base } \\
(\mathrm{m})\end{array}$ & $\begin{array}{c}\text { True } \\
\text { resistivity } \\
(\Omega \mathrm{m})\end{array}$ & Lithology \\
\hline 0 & 92.14 & 16.41 & Claystone \\
\hline 92.14 & 114.29 & 16.39 & Claystone \\
\hline 114.29 & 154.71 & 8.65 & Claystone \\
\hline 154.71 & 202.9 & 16.73 & Claystone \\
\hline 202.9 & 244.28 & 7.89 & Claystone \\
\hline 244.28 & 263.79 & 25.71 & Sandstone \\
\hline 263.79 & 1991.02 & 6.47 & Claystone \\
\hline 1991.02 & 10000 & 1.84 & Claystone \\
\hline
\end{tabular}

Tabel 8. Resistivitas sebenarnya dan ketebalan lapisan pada titik BN03

\begin{tabular}{|r|r|r|l|}
\hline $\begin{array}{c}\text { Depth } \\
\text { to Top } \\
(\mathrm{m})\end{array}$ & $\begin{array}{c}\text { Depth } \\
\text { to base } \\
(\mathrm{m})\end{array}$ & $\begin{array}{c}\text { True } \\
\text { resistivity } \\
(\Omega \mathrm{m})\end{array}$ & Lithology \\
\hline 0 & 49.92 & 8.15 & Claystone \\
\hline 49.92 & 70.52 & 33.48 & Sandstone \\
\hline 70.52 & 71.01 & 17.5 & Claystone \\
\hline 71.01 & 176.2 & 6.47 & Claystone \\
\hline 176.2 & 872.96 & 11.17 & Claystone \\
\hline 872.96 & 2028.36 & 6.01 & Claystone \\
\hline 2028.36 & 5056.34 & 0.62 & Claystone \\
\hline 5056.34 & 10000 & 2.05 & Claystone \\
\hline
\end{tabular}

Tabel 9. Resistivitas sebenarnya dan ketebalan lapisan pada titik BN04

\begin{tabular}{|r|c|r|l|}
\hline $\begin{array}{c}\text { Depth } \\
\text { to Top } \\
(m)\end{array}$ & $\begin{array}{c}\text { Depth } \\
\text { to base } \\
(m)\end{array}$ & $\begin{array}{c}\text { True } \\
\text { resistivity } \\
(\Omega m)\end{array}$ & Lithology \\
\hline 0 & 74.72 & 19.75 & Claystone \\
\hline 74.72 & 268.56 & 11.25 & Claystone \\
\hline
\end{tabular}




\begin{tabular}{|r|r|r|l|}
268.56 & 279.81 & 16.51 & Claystone \\
\hline 279.81 & 509.27 & 9.24 & Claystone \\
\hline 509.27 & 1080.66 & 18.87 & Claystone \\
\hline 1080.66 & 3522.34 & 1.65 & Claystone \\
\hline 3522.34 & 4322.79 & 29.77 & Sandstone \\
\hline 4322.79 & 10000 & 90.89 & Sandstone \\
\hline
\end{tabular}

Tabel 10. Resistivitas sebenarnya dan ketebalan lapisan pada titik BN05

\begin{tabular}{|r|r|r|l|}
\hline $\begin{array}{c}\text { Depth } \\
\text { to } \\
\text { Top } \\
(m)\end{array}$ & $\begin{array}{c}\text { Depth } \\
\text { to } \\
\text { base } \\
(m)\end{array}$ & $\begin{array}{c}\text { True } \\
\text { resistivity } \\
(\Omega m)\end{array}$ & Lithology \\
\hline 0 & 27.93 & 3.18 & Claystone \\
\hline 27.93 & 47.94 & 9.73 & Claystone \\
\hline 47.94 & 48.97 & 11.68 & Claystone \\
\hline 48.97 & 112.76 & 4.35 & Claystone \\
\hline 112.76 & 166.71 & 11.87 & Claystone \\
\hline 166.71 & 375.01 & 21.32 & Sandstone \\
\hline 375.01 & 439.29 & 5.68 & Claystone \\
\hline 439.29 & 10000 & 4.08 & Claystone \\
\hline
\end{tabular}

Tabel 11. Resistivitas sebenarnya dan ketebalan lapisan pada titik BN06

\begin{tabular}{|c|c|c|c|}
\hline $\begin{array}{c}\text { Depth } \\
\text { to Top } \\
(\mathrm{m})\end{array}$ & $\begin{array}{c}\text { Depth } \\
\text { to base } \\
(\mathrm{m})\end{array}$ & $\begin{array}{c}\text { True } \\
\text { resistivity } \\
(\Omega \mathrm{m})\end{array}$ & Lithology \\
\hline 0 & 49.21 & 7.27 & Claystone \\
\hline 49.21 & 67.33 & 18.94 & Claystone \\
\hline 67.33 & 71.23 & 17.16 & Claystone \\
\hline 71.23 & 132.43 & 7.17 & Claystone \\
\hline 132.43 & 195.33 & 12.56 & Claystone \\
\hline 195.33 & 1910.60 & 7.66 & Claystone \\
\hline 1910.60 & 4598.23 & 3.70 & Claystone \\
\hline 4598.23 & 10000 & 4.97 & Claystone \\
\hline
\end{tabular}

Tabel 12. Nilai resistivitas batuan

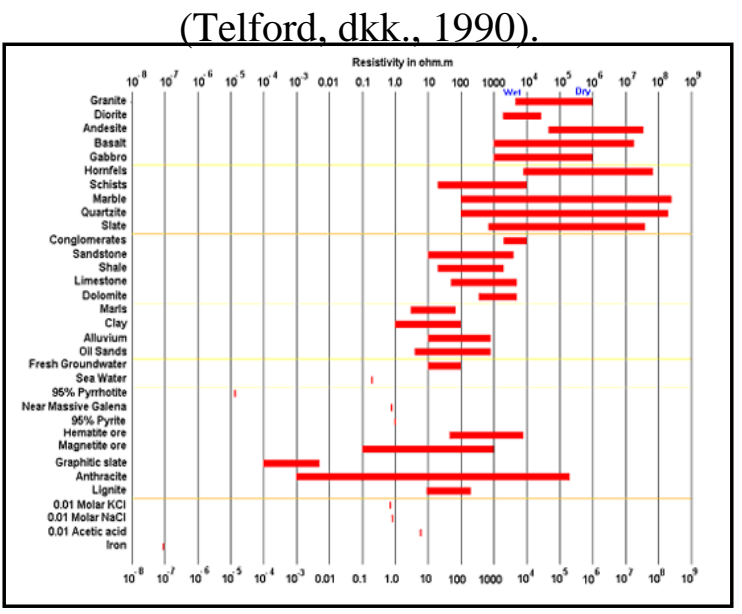

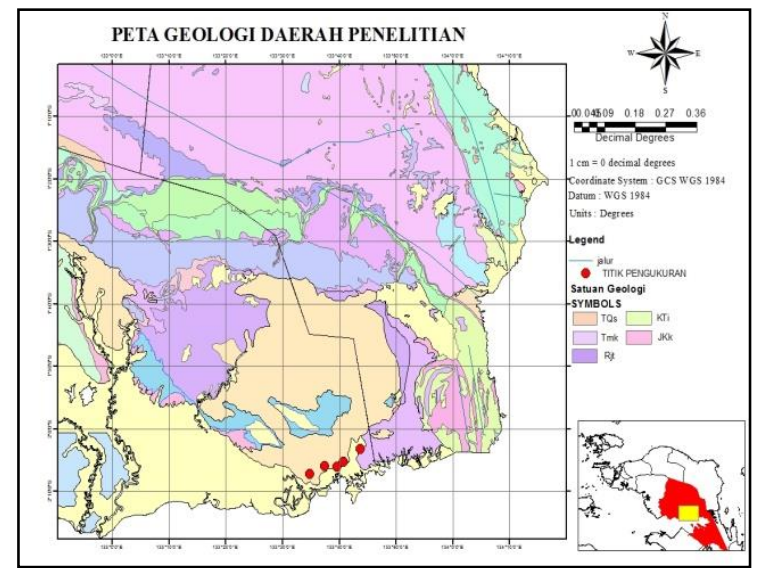

Gambar 1. Peta Geologi Daerah Penelitian (SRTM-90)

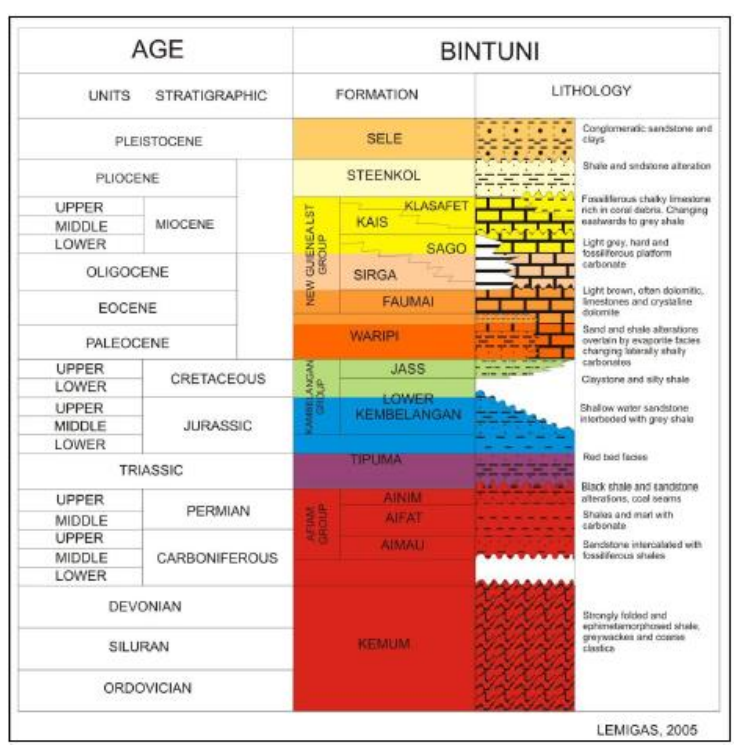

Gambar 2. Kolom Stratigrafi Cekungan Bintuni (LEMIGAS, 2005).

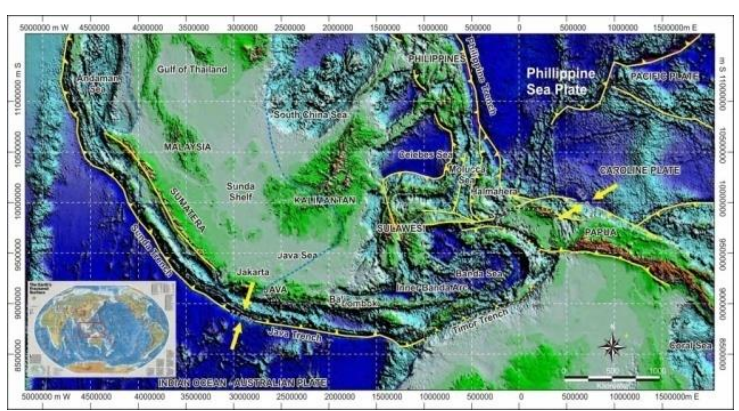

Gambar 3. Elemen tektonik Indonesia dan pergerakan lempeng tektonik (Hamilton, 1979). 


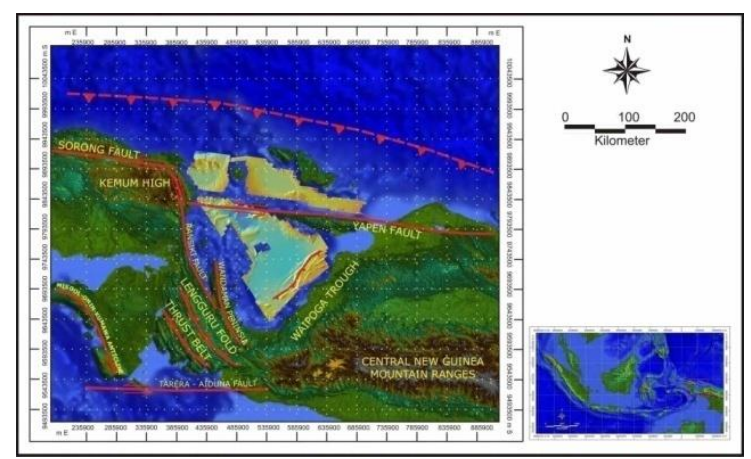

Gambar 4. Struktur Regional Papua (Dow dan Sukamto, 1984).

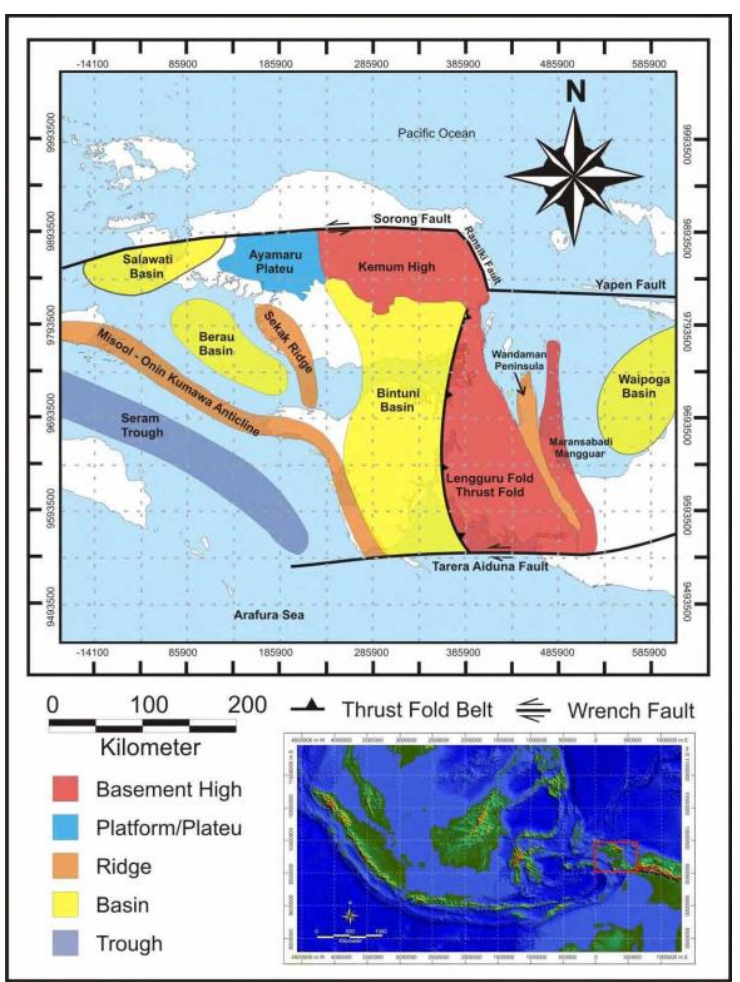

Gambar 5. Elemen Tektonik Kepala Burung (Pigram dkk., 1982).

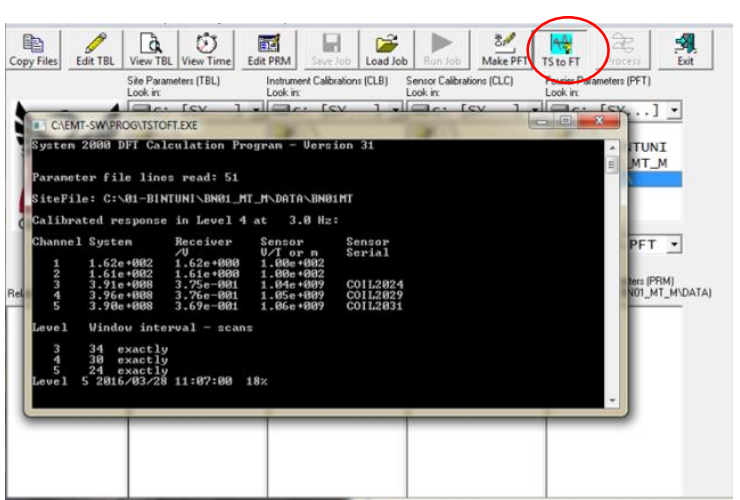

Gambar 6. Proses FFT

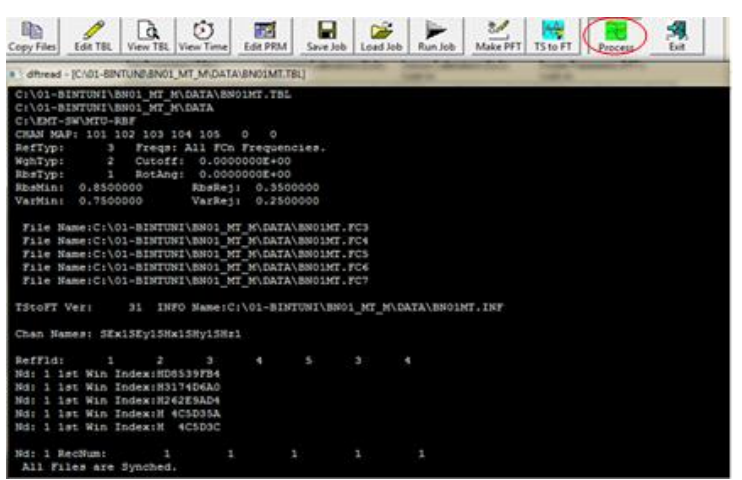

Gambar 7. Tampilan Robust Processing

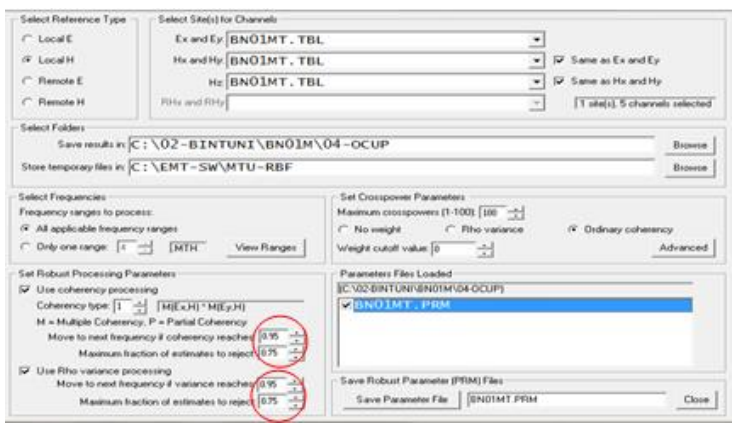

Gambar 8. Tampilan Setting Robust Processing Upgrade

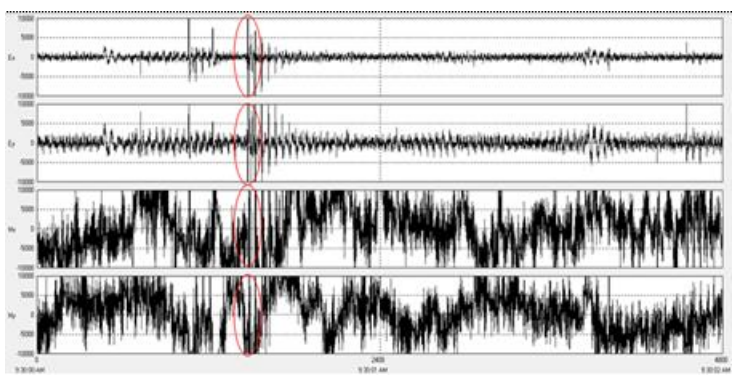

Gambar 9. Seleksi Time Series

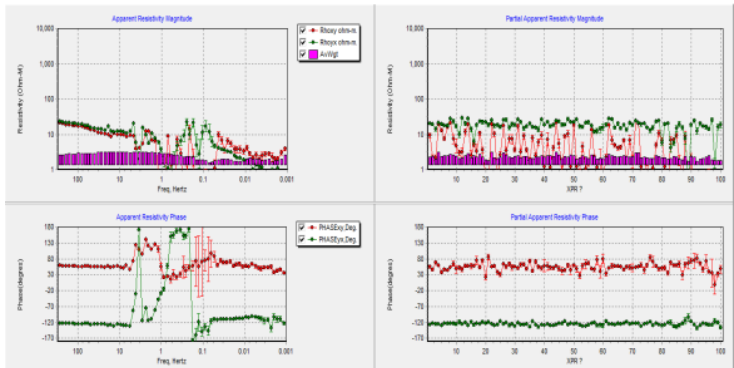

Gambar 10a. Kurva Sebelum Seleksi Cross Power 
Jurnal Geofisika Eksplorasi Vol /No.

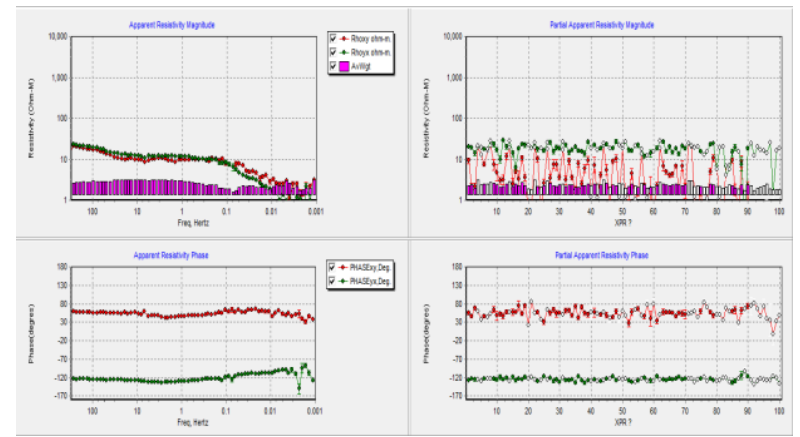

Gambar 10b. Kurva Setelah Seleksi Cross Power

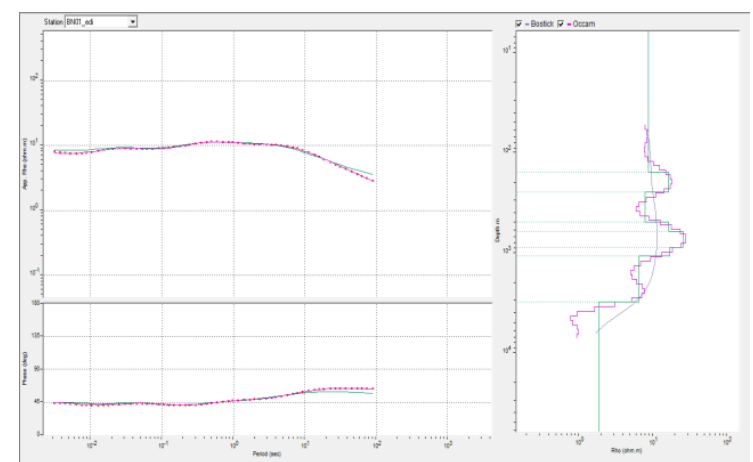

Gambar 11. Pemodelan Sounding 1D 